\title{
Изучение генетической регуляции накопления кутикулярного воска ячменя при помощи анализа данных RNA-seq
}

\author{
Вихорев А. ${ }^{1,2 *}$, Шмаков Н. ${ }^{1}$, Колосовская Е. ${ }^{1,2}$, Короткова А. ${ }^{1}$, Герасимова С. ${ }^{1,2}$, Хлесткина Е. ${ }^{1,2,3}$ \\ ${ }^{1}$ Институт цитологии и генетики СО РАН, Новосибирск, Россия \\ ${ }^{2}$ Новосибирский государственный университет, Новосибирск, Россия \\ ${ }^{3}$ ФИЦ Всероссийский институт генетических ресурсов растений имени Н.И. Вавилова, Санкт-Петербург, Россия \\ *e-mail: vikhorev@bionet.nsc.ru
}

Ключевые слова: ячмень, Hordeum vulgare, эпикутикулярный воск, RNA-seq

Мотивация и цель: Наличие и строение эпикутикулярного воскового покрова является селекционно-важным признаком ячменя, связанным с защитой от внешних неблагоприятных факторов. Однако на данный момент генетика этого признака слабо изучена. Ранее была получена линия ячменя winl c нокаутированным геном HvWIN1. Для этой линии было показано отсутствие бета-дикетонов на поверхности листового влагалища. Цель данной работы - изучение генетической регуляции накопления эпикутикулярного воска ячменя при помощи анализа изменений в экспрессии генов мутантной линии win1 по гену HvWIN1.

Meтоды и алгоритмы: Была секвенирована РНК из листовых пластинок и листовых влагалищ двух линий $H$. vulgare: дикий тип и мутантная линия win1. Для каждого образца было взято по четыре биологических повторности. Оценка качества прочтений была произведена при помощи FASTQC, предобработка была произведена в программе Trimmomatic. Для картирования прочтений использовалась программа DART, квантификации осуществлялась при помощи функции featureCounts пакета Subread. Поиск дифференциально экспрессирующихся генов (ДЭГ) был произведен при помощи edgeR. Аннотация ДЭГов была осуществлена при помощи AgriGO и BlastKOALA.

Результаты: Всего было секвенировано 16 библиотек РНК, прошедшие предобработку библиотеки содержат 440 млн (94\%) прочтений. Успешно картировались на референсный геном в среднем $98,76 \%$ прочтений. После удаления генов со слишком низкой экспрессией было обнаружено, что 26807 из 39841 генов ячменя (67,3\%) имеют значимую экспрессию в исследуемых органах. Всего было обнаружено 808 генов с повышенной и 765 генов с пониженной экспрессией в листовой пластинке линии win1, а также 605 генов с повышенной и 81 ген с пониженной экспрессией в листовом влагалище линии win1 (при пороге $|\log \mathrm{FC}|>2$, FDR $<0.05$ ). Среди генов с повышенной экспрессией были обнаружены гены, связанные с синтезом жирных кислот и компонентов клеточной стенки. Среди генов с пониженной экспрессией были обнаружены гены, ассоциированные с синтезом компонентов эпикутикулярного воска.

Заключение: Были найдены и аннотированы гены, изменяющие экспрессию после нокаута гена HvWIN1. Полученные результаты позволят выявить конкретные гены, участвующие в синтезе эпикутикулярного воска у ячменя.

Благодарности: Работа выполнена при поддержке РНФ № 16-14-00086. 